\title{
THE EFFECT OF CLIMATE ON TOTAL PHENOLICS IN MACROTYLOMA UNIFLORUM, VIGNA UNGUICULATA, CINNAMOMUM ZEYLANICUM AND MENTHA PIPERITA USING SPECTROPHOTOMETER
}

\author{
VASUNDHARA SAXENA*, CHAGTI KK \\ Department of Pharmacy, Smt. Vidyawati College of Pharmacy, Jhansi, Uttar Pradesh, India. Email: vidhi.saxena@yahoo.co.in \\ Received: 10 March 2016, Revised and Accepted: 19 March 2016
}

\section{ABSTRACT}

Objective: Polyphenolic compound which is proven as antioxidants and possesses a chemo - protective potential are found in leaves, flowers, fruits, and bark. The aim of the study was to estimate the amount of tannins present in these drugs using Folin-Denis method. This study was conducted to evaluate the variations in the total amount of secondary metabolites (poly-phenolic) during summer and winter seasons in the leaves of four important valuable medicinal plants, viz., Macrotyloma uniflorum, Vigna unguiculata, Cinnamomum zeylanicum, and Mentha piperita using ultravioletvisible spectrophotometry.

Methods: Tannin contents of plants were measured by Folin-Denis method. Tannin-like compounds reduce phosphotungstomolybdic acid in alkaline solution to produce a highly colored blue solution, the intensity of which is proportional to the amount of tannins present. The intensity is measured in a spectrophotometer at $650 \mathrm{~nm}$.

Results: The concentration was almost same for Mu1 and Mu2 plant with little effect of seasonal variations and at the same place it was found to be maximum in Cz1. The concentration curve for tannic acid was determined, and the correlation coefficient was calculated and was found to be 1 which indicates the good linearity between the concentration and the absorbance.

Conclusion: The maximum amounts of secondary metabolites (poly-phenolic) were observed during summer, while minimum in winter season with an exception of Mu2 plant. Thus, this study was used as one of the parameters for standardization of medicinal plants.

Keywords: Macrotyloma uniflorum, Vigna unguiculata, Cinnamomum zeylanicum, Mentha piperita tannins, Total phenolics, Folin-Denis method.

(C) 2016 The Authors. Published by Innovare Academic Sciences Pvt Ltd. This is an open access article under the CC BY license (http://creativecommons. org/licenses/by/4. 0/) DOI: http://dx.doi.org/10.22159/ajpcr.2016.v9i5.11643

\section{INTRODUCTION}

Tannins and tannin-like substances are widespread in nature and are probably present in all plant materials. These are polyphenolic compounds divided into two main groups - hydrolysable and condensed. Hydrolysable tannins contain a polyhydric alcohol usually, if not always, glucose esterified with gallic acid or with hexahydroxydiphenic acid. Condensed tannins are mostly flavonols and are probably polymers of flavan-3-ol (catechin), and these cannot be hydrolyzed to simple components. Among different chemical constituents, polyphenols (flavonoids, phenolics, condensed and hydrolysable tannins) are major bioactive compounds responsible for the prevention of chronic diseases and health care $[1,2]$. The therapeutic properties of herbal drugs are due to the presence of secondary metabolites which varies according to their age, seasons and maturity. They have been reported to exert antiinflammatory, antimicrobial, antioxidant, anticarcinogenic, and body mass reducing activities. Phenolic compounds are a unique category of phytochemicals especially in terms of their vast potential healthbenefiting properties [3-5]. They have multiple biological effects and also act as antioxidants by preventing the oxidation of low-density lipoproteins, platelet aggregation, and damage of red blood cells. Some of these substances have antifungal, antibacterial, anticancer, and hepatoprotective effects [6-10]. Horse gram (Macrotyloma uniflorum Lam.) is a popular pulse, locally known as Gaheth belongs to the family Fabaceae that still remain an under-exploited legume crop. Horse gram seeds are rich in protein and consumed in the majority by poorest section of the society [11]. Vigna unguiculata subsp. unguiculata (black colored seed coat) is a less known pulse possessing high nutritional quality [12]. The cowpea ( $V$. unguiculata $\mathrm{L}$. Walp) is considered a grain legume or pulse which is potential agent of reducing serum lipids and glucose. Mentha piperita L. or peppermint with the vernacular name of "nana felfeli," a plant from the Labiatae family, is traditionally used as an antiseptic, stimulant, carminative agent or it is further used as a flavoring agent in cosmetic and pharmaceutical industries worldwide [13]. Cinnamon (Cinnamomum verum, synonym Cinnamomum zeylanicum) is a small evergreen tree, 10-15 m (32.8-49.2 feet) tall, belonging to the family Lauraceae, native to Sri Lanka and South India. In medicine, it acts like other volatile oils and once had a reputation as a cure for colds. It has also been used to treat diarrhea and other problems of the digestive system [14]. Environmental conditions affect the plant growth as well as the formation of secondary metabolites, as they are mostly formed in young and actively growing tissues [15]. Thus, the seasonal changes have an effect on the physiological parameters. Therefore, this study was conducted to have a better understanding of plant metabolic products under seasonal influences in four important medicinal plants, viz., $M$. uniflorum, V. unguiculata, C. zeylanicum, and M. piperita; these plants are used in curing various diseases such as in urinary troubles.

\section{METHODS}

\section{Principle}

Tannin-like compounds reduce phosphotungstomolybdic acid in alkaline solution to produce a highly colored blue solution, the intensity of which is proportional to the amount of tannins. The intensity is measured in a spectrophotometer at $650 \mathrm{~nm}$. Tannin contents of plants were measured by Folin-Denis method $[16,17]$.

\section{Preparation of Folin-Denis reagent}

Sodium tungstate $(100 \mathrm{~g})$ and phosphomolybdic acid (20 g) were dissolved in $650 \mathrm{ml}$ distilled water and later $50 \mathrm{ml}$ of phosphoric acid was added into the solution. The mixture was refluxed for $2 \mathrm{hrs}$ and volume was made to $1 \mathrm{~L}$ with distilled water.

\section{Preparation of carbonate solution}

Sodium carbonate $(350 \mathrm{~g})$ was dissolved in $1 \mathrm{~L}$ water at $70^{\circ} \mathrm{C}$. Solution was allowed to stand overnight, and then, it was filtered through glass-wool. 
Preparation of standard tannic acid solution

Tannic acid (100 g) was dissolved in $100 \mathrm{ml}$ distilled water.

\section{Preparation of working solution}

About $5 \mathrm{ml}$ stock solution was diluted to $100 \mathrm{ml}$ with distilled water. Each ml contained $50 \mu \mathrm{g}$ of tannic acid.

\section{Collection and preparation of plant}

The plant materials were collected in two seasons, i.e., summer collection in the month of July and winter collection in the month of January from the local area. The samples collected were washed, dried and authenticated and were coded are shown in Table 1.

\section{Method preparation of standard curve}

About $10 \mathrm{ml}$ of standard solution was made up to $100 \mathrm{ml}$ distilled water. $1-10 \mathrm{ml}$ aliquots were taken in clear test tubes. $0.5 \mathrm{ml}$ of FolinDenis reagent and $1 \mathrm{ml}$ of sodium carbonate solution was added to each tube. Each tune was made up to $10 \mathrm{ml}$ with distilled water. All the reagents in each tube were mixed well and kept undisturbed for about 30 minutes and read at $650 \mathrm{~nm}$ against reagent blank (Fig. 1) [18,19].

\section{Extraction of tannin}

Accurately weighed $0.5 \mathrm{~g}$ of the powdered material was transferred to a $250 \mathrm{ml}$ conical flask. Add $75 \mathrm{ml}$ water. Heat the flask gently and boil for 30 minutes. Centrifuged at $2000 \mathrm{rpm}$ for 20 minutes and collect the supernatant in $100 \mathrm{ml}$ volumetric flask and make up the volume. Transfer $1 \mathrm{ml}$ of the sample extract to a $100 \mathrm{ml}$ volumetric flask containing $75 \mathrm{ml}$ water. Add $5 \mathrm{ml}$ of Folin-Denis reagent, $10 \mathrm{ml}$ of sodium carbonate solution and dilute to $100 \mathrm{ml}$ with water and shaken well. Read the absorbance at $650 \mathrm{~nm}$ after 30 minutes.

\section{Estimation of sample}

An aliquot of the sample extract containing not more than $0.5 \mathrm{mg}$ of tannic acid was used, and the percentage of tannin was determined.

\section{RESULTS}

\section{Calculation}

The tannin concentration was determined by the standard graph of tannic acid solution shown in Table 2.

Table 1: Coding of samples in different seasons

\begin{tabular}{llll}
\hline S. No. & Plants studied on & $\begin{array}{l}\text { Summer } \\
\text { collection }\end{array}$ & $\begin{array}{l}\text { Winter } \\
\text { collection }\end{array}$ \\
\hline 1 & M. uniflorum & $\mathrm{Mu} 1$ & $\mathrm{Mu} 2$ \\
2 & V. unguiculata & $\mathrm{Vu} 1$ & $\mathrm{Vu} 2$ \\
3 & C. zeylanicum & $\mathrm{Cz} 1$ & $\mathrm{Cz} 2$ \\
4 & M. piperita & $\mathrm{Mp} 1$ & $\mathrm{Mp} 2$ \\
\hline
\end{tabular}

M. uniflorum: Macrotyloma uniflorum, V. unguiculata: Vigna unguiculata,

C. zeylanicum: Cinnamomum zeylanicum, M. piperita: Mentha piperita

Table 2: Absorbance and concentration of total phenol in all samples

\begin{tabular}{llll}
\hline S. No. & Samples & $\begin{array}{l}\text { Absorbance } \\
\text { at } 650 \mathbf{~ n m}\end{array}$ & Concentration (ug) \\
\hline 1 & Mu1 & 0.134 & 1.34 \\
2 & Vu1 & 0.088 & 0.88 \\
3 & Cz1 & 0.227 & 2.27 \\
4 & Mp1 & 0.095 & 0.95 \\
5 & Mu2 & 0.128 & 1.28 \\
6 & Vu2 & 0.049 & 0.49 \\
7 & $\mathrm{Cz} 2$ & 0.071 & 0.71 \\
8 & Mp2 & 0.083 & 0.83 \\
\hline
\end{tabular}

Statistical analysis

The different samples of two seasons, i.e., summer collection in the month of July and winter collection in the month of January were analyzed, each one in triplicate. All values are means \pm standard deviation of three samples. Statistical analysis was performed using a one-way analysis of variance, followed by Tukey's multiple comparison test. Differences at $\mathrm{p}<0.05$ were considered statistically significant.

\section{DISCUSSON}

The concentration curve for tannic acid was determined and the correlation coefficient was calculated and was found to be 1 which indicates the good linearity between the concentration and the absorbance. The results revealed that maximum amount of secondary metabolites (poly-phenolic) were observed during summer, while minimum in winter season. The concentration was almost same for Mu1 and Mu2 plant with little effect of seasonal variations and at the same place it was found to be maximum in Cz1. Tannins are complex

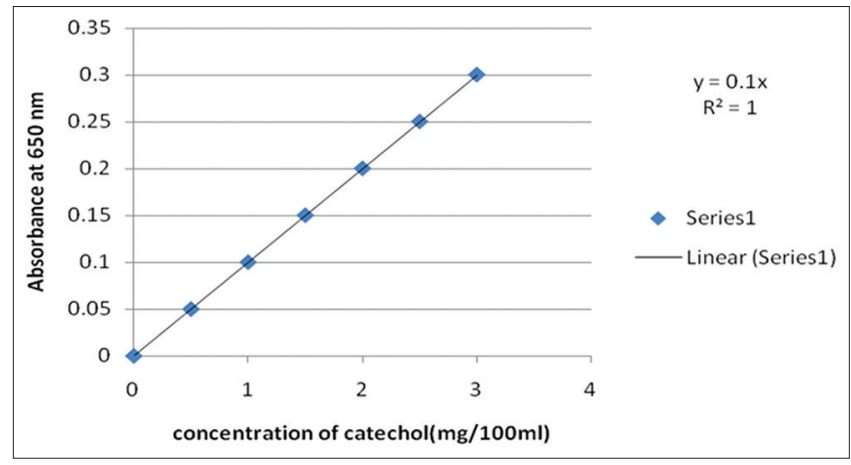

Fig. 1: Standard curve

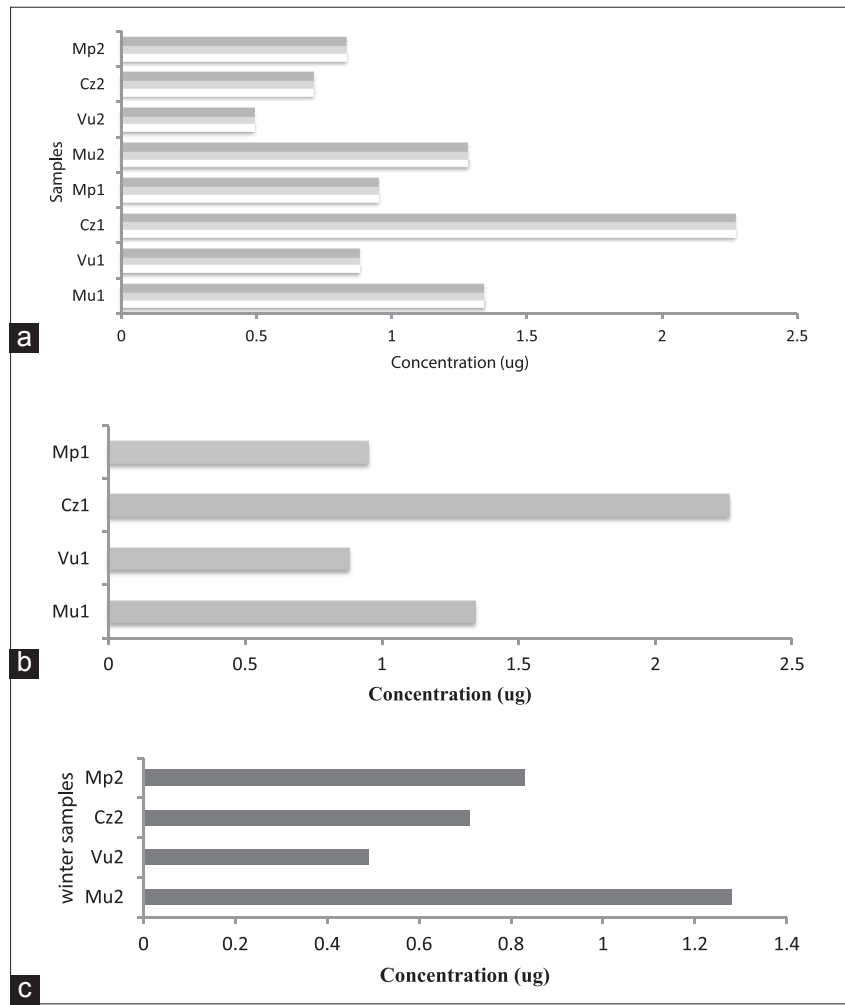

Fig. 2: (a) Concentration of total phenol in samples,

(b) comparison among summer samples, (c) concentration of total phenol in winter collection 
secondary metabolites having various medicinal properties but difficult to isolate in pure form. Tannins are polyphenols, have a large influence on the nutritive value of humans and animals foodstuff. Recent interest in phenolic compounds due to their protective role, through utilization of fruits and indigenous vegetables such as apple, black caraway, carrot, cranberry, orange, and tomato against oxidative damage diseases such as arteriosclerosis, cardiovascular, coronary heart disease, aging, stroke, and cancer [20]. Many plants have been studied and reported the importance of tannins and its variation. Further study is necessary to understand the factors which may affect the production of tannins (Fig. 2).

\section{CONCLUSION}

In general, harvesting season affected the chemical composition. A significant variation in the content of total phenolics was documented. The maximum amounts of secondary metabolites (poly-phenolic) were observed during summer, while minimum in winter season with an exception of Mu2 plant. Thus present study was used as one of the parameters for standardization of medicinal plants and the information observed on seasonal variation may be useful in selecting the best season for optimal yield of the secondary metabolite of pharmaceutical importance.

\section{REFERENCES}

1. Kirtikar KR, Basu BD. Indian Medicinal Plants. Allahabad, India: Lalit Mohan Basu; 1956. p. 2045-8

2. Nadkarni KM. Indian Materia Medica. Bombay: Bombay Prakashan; 1982. p. 787.

3. Asolkar LV, Kakkar KK, Chakre OJ. Glossary of Indian Medicinal Plants with Active Principal, Part-I. Publications and Information Directorate. New Delhi: Council of Scientific and Industrial Research Publication; 1956. p. 165.

4. Chopra RN, Nayer SL, Chopra IC. Glossary of Indian Medicinal Plants. New Delhi, India: Council of Scientific and Industrial Research; 1956. p. 255-8.
5. Conners KA. A Textbook of Pharmaceutical Analysis. $3^{\text {rd }}$ ed. New York John Wiley and Sons, A Wiley-Inter Science Publication; 1999. p. 595.

6. Despande SS, Shah GB, Parmar NS. Antiulcer activity of Tephrosia purpurea in rats. Indian J Pharmacol 2003;35:168-72.

7. Dhar ML, Dhar MM, Dhawan BN, Mehrotra BN, Ray C. Screening of Indian plants for biological activity: I. Indian J Exp Biol 1968;6(4):232-47.

8. Jain UK, Dixit VK. Spectrophotometric estimation of tannins from chyavanprash. Indian Drugs 2004;41:469.

9. Khatri A, Garg A, Agrawal SS. Evaluation of hepatoprotective activity of aerial parts of Tephrosia purpurea L. and stem bark of Tecomella undulata. J Ethnopharmacol 2009;122(1):1-5.

10. Peach EK, Tracy MV. Modern Methods of Plant Analysis. Vol. III. Berlin: Springer Verlag Publication; 1915. p. 332-50.

11. Prakash BG, Guled MB, Bhosale AM. Identification of suitable horse gram varieties for Northern dry zone of Karnataka. Karnataka J Agric Sci 2008;21(3):343-5.

12. Arinathan V, Mohan VR, John De Britto A. Chemical composition of certain tribal pulses in South India. Int $\mathrm{J}$ Food Sci Nutr 2003;54(3):209-17.

13. Mahboubi M, Kazempour N. Chemical composition and antimicrobial activity of peppermint (Mentha piperita L.) essential oil. Songklanakarin. J Sci Technol 2014;36(1): 83-7.

14. Jakhetia V, Patel R, Khatri P. Cinnamon: A pharmacological review. J Adv Sci Res 2010;1(2):19-23.

15. Waller GR, Nowacki EK. Alkaloid Biology and Metabolism in Plants. New York: Plenum Press; 1978. p. 135.

16. Ram PR, Mehrotra BN. Compendium of Indian Medicinal Plants, (Drug Research Preparative: A CDRI Series). Vol. 2. New Delhi: Centra Drug Research Institute, Lucknow and Publications and Information Directorate; 1993. p. 453.

17. Sane RT. Standardization, quality control, and GMP for herbal drug. Indian Drugs 2002;39:184.

18. Sastri BN. The Wealth of India. New Delhi, India: Publication and Information Directorate, CSIR, Hillside; 1962. p. 336.

19. Schanderl SH. Method in Food Analysis. New York: Academic Press; 1970. p. 709

20. Abdi S, Ali A. Role of ROS modified human DNA in the pathogenesis and etiology of cancer. Cancer Lett 1999;142(1):1-9. 